Bangladesh J. Bot. 36(2): 93-103, 2007 (December)

\title{
MICROMORPHOLOGY AND ANATOMY OF THREE SYMPHYTUM (BORAGINACEAE) TAXA FROM TURKEY
}

\author{
Oznur Ergen Akcin and Hilal Baki \\ Department of Biology, Sciences \& Arts Faculty, Ordu University, Ordu, Turkey \\ E-mail: oakcin@omu.edu.tr
}

Key words: Micromorphology, Anatomy, Symphytum

\begin{abstract}
Symphytum asperum Lepechin, S. ibericum Steven and S. sylvaticum Boiss. were examined morphologically, micromorphologically and anatomically. Scanning electron microscopy was used to examine leaf surface and trichomes of these species. These species had bifacial and hypostomatous leaf types. Epidermal cells of leaves were usually polygonal or irregular in form. The pattern of anticlinical cells may vary in different species and between the upper and lower epidermis of the same species. Stomata are anisocytic and anomocytic in three species. Stomata index is 27.5 for S. sylvaticum, 24.65 for S. ibericum and 21.86 for $S$. asperum glandular trichomes are capitate in forms and more dense on the lower epidermis than upper epidermis. Eglandular trichomes are simple, short or long, unicellular or multicellular and thin or thick.
\end{abstract}

\section{Introduction}

Symphytum L. (Boraginaceae) is represented by about 23 taxa in Turkey (Wickens 1978, Yildirimli 2000). Symphytum species are common garden plants and have been used as a source of herbal medicines for $>2000$ years. Leaf and root of Symphytum species are used by lay public, herbalists and physicians for treatment of broken bones, tendon damage, ulcerations in the gastrointestinal tract, and lung congestion. These species are also rich in many crucial nutrients, such as protein, antioxidant, vitamins and vitamin B12, and are common component in the diet of certain ethnic groups (Hills 1976, Rode 2002). Some Symphytum species are also used as remedies in Anatolian folk medicines and as ornamental plants in gardens and parks (Gürbüz 1980, Baytop 1984).

In recent years, this genus has been the subject of chemical and chemotaxonomical studies (Dudkin and Denisyuk 1984, Jaarsma et al. 1989, Chushenko et al. 1990). There is no detailed study on anatomical and micromorphological properties. Metcalfe and Chalk (1979) and Watson and Dallwitz (1991) mentioned about characteristic properties of the family Boraginaceae.

Symphytum is a mesophytic genus. Many of the Turkisk species are rare or local (Wickens 1978). Anatomical properties are very important characters in Symphytum. The main objective of this study is to explore the micromorphological and anatomical properties of North Anatolian representatives of three Symphytum taxa (S. asperum Lepechin, S. ibericum Steven and $S$. sylvaticum Boiss.).

\section{Materials and Methods}

Plant materials were collected from north Anatolia in 2004 and 2006 and were kept at the Ondokuz Mayis University Herbarium. The collection data for the specimens are given in Table 1. Taxonomical descriptions of the specimens were made according to Wickens (1978). Samples for anatomical studies were fixed in $70 \%$ alcohol. All measurements were recorded with an ocularmicrometer on a light microscope (Tables 2 and 3). For anatomical analysis, cross sections of root, stem and leaves and surface sections of leaves were used. Their photographs were taken with Nikon FDX-35 microscope. Stomata index was calculated according to the method described by Meidner and Mansfield (1968). For scanning electron microscopy, dried leaves were mounted on 
stubs using double-sided adhesive tape. Samples were coated with 12.5- $15 \mathrm{~nm}$ of gold. Coated leaves were examined and photographed with JMS-6400 Scanning Electron Microscope.

Table 1. Locality information of the Symphytum taxa.

\begin{tabular}{ll}
\hline Taxa & Locality \\
\hline & A7 Trabzon: Maçka- Hamsiköy, $1250 \mathrm{~m}$, Baki 1008. \\
S. asperum Lepechin & A7 Trabzon: Maçka, $1270 \mathrm{~m}$, Baki 1007. \\
& A7 Giresun: Tamdere, $1700 \mathrm{~m}$, Baki 1004. \\
S. ibericum Steven & A6 Ordu: Perşembe, $10 \mathrm{~m}$, Baki 1001. \\
& A7 Trabzon: Road sides, $50 \mathrm{~m}$, Baki 1010. \\
S. sylvaticum Boiss. & A7 Trabzon: Maçka- Hamsiköy, $1250 \mathrm{~m}$, Baki 1009. \\
& A7 Giresun: Tamdere, $1400 \mathrm{~m}$, Baki 1003. \\
\hline
\end{tabular}

\section{Results and Discussion}

Morphological properties

Symphytum asperum: Perennial. Stem $30-90 \mathrm{~cm}$, hairy. Leaves ovate to elliptic-lanceolate. Basal leaves petiolate, cauline leaves shortly petiolate. Inflorescence helicoid cymes. Calyx 3-5 $\mathrm{mm}$, hairy. Corolla pink at first, turning blue or lilac, 11-12 mm. Nutlets 3-4 mm, base constricted, brown-dark brown (Fig. 1A, 1B).

Symphytum ibericum: Perennial. Stem 27-38 cm. Leaves ovate to ovate-lanceolate. Basal leaves petiolate, cauline leaves shortly petiolate. Inflorescence cymes. Calyx 4-5 mm, hairy. Corolla cream, 14-15 mm. Nutlets 2-3 mm, brown and minutely tuberculate (Fig. 2A, 2B).

Symphytum sylvaticum: Perennial. Stem $36-48 \mathrm{~cm}$. Leaves oblong-lanceolate, acute or acuminate. Basal leaves petiolate, cauline leaves sessile. Inforescence scorpoid cymes to helicoid cymes. Pedicels 5-7 mm. Calyx 5-7 in flowers, 6-11 in fruits. Corolla white, 11-13 mm. Nutlets 3$4.5 \mathrm{~mm}$, subglobose, minutely tuberculate (Fig. 3A, 3B).

Table 2. Stomata features on the lower surface of leaves of Symphytum species.

\begin{tabular}{|c|c|c|c|}
\hline & $\begin{array}{l}\text { S. asperum } \\
\text { Mean } \pm \mathrm{SE}\end{array}$ & $\begin{array}{l}\text { S. ibericum } \\
\text { Mean } \pm \text { SE }\end{array}$ & $\frac{\text { S. sylvaticum }}{\text { Mean } \pm \mathrm{SE}}$ \\
\hline Number of stomata $\left(1 \mathrm{~mm}^{2}\right)$ & $54.4 \pm 2.614$ & $43.2 \pm 2.445$ & $61.6 \pm 2.401$ \\
\hline $\begin{array}{l}\text { Number of epidermis cell } \\
\left(1 \mathrm{~mm}^{2}\right)\end{array}$ & $194.4 \pm 6.86$ & $132 \pm 4.174$ & $162.4 \pm 4.310$ \\
\hline Stomata length $(\mu)$ & $25 \pm 0.745$ & $18 \pm 0.5$ & $17.25 \pm 1.028$ \\
\hline Stomata width $(\mu)$ & $17.25 \pm 0.692$ & $26.5 \pm 0.928$ & $24.5 \pm 0.898$ \\
\hline Stoma index & 21.86 & 24.65 & 27.5 \\
\hline
\end{tabular}

Anatomical properties

Symphytum asperum: A transverse section taken from the root was observed and the anatomical features were as follows (Fig. 4). Periderm is multilayered. Phelloderm is clear. Cortex is 10-13 layered and parenchymatic. Parenchymatic cells are $29.25 \pm 1.82 \times 9.5 \pm 1.04 \mu$. Cambium cells are undistinguishable. Xylem is composed of sclerenchymatic cells and tracheary elements. Pith rays are present. The pith consists of primary xylem elements (Table 3 ).

A transverse section taken from the middle part of the stem was observed (Fig. 5). Epidermal cells consist of a single layer and orbicular or rectangular. Trichomes are present on the cuticle. Collenchyma is 3-4 layered. Cortex cells are $78.25 \pm 5.43 \times 51.25 \pm 5.88 \mu$ and multilayered. Endodermis is between cortex and vascular tissue. The vascular tissues are collateral. Bundles are 
of different sizes. Xylem and phloem elements are clear. Cambium is distinguishable. Diameter of vessel members are $35.5 \pm 6.4 \mu$. The pith consists of large parenchymatic cells (Table 3 ).
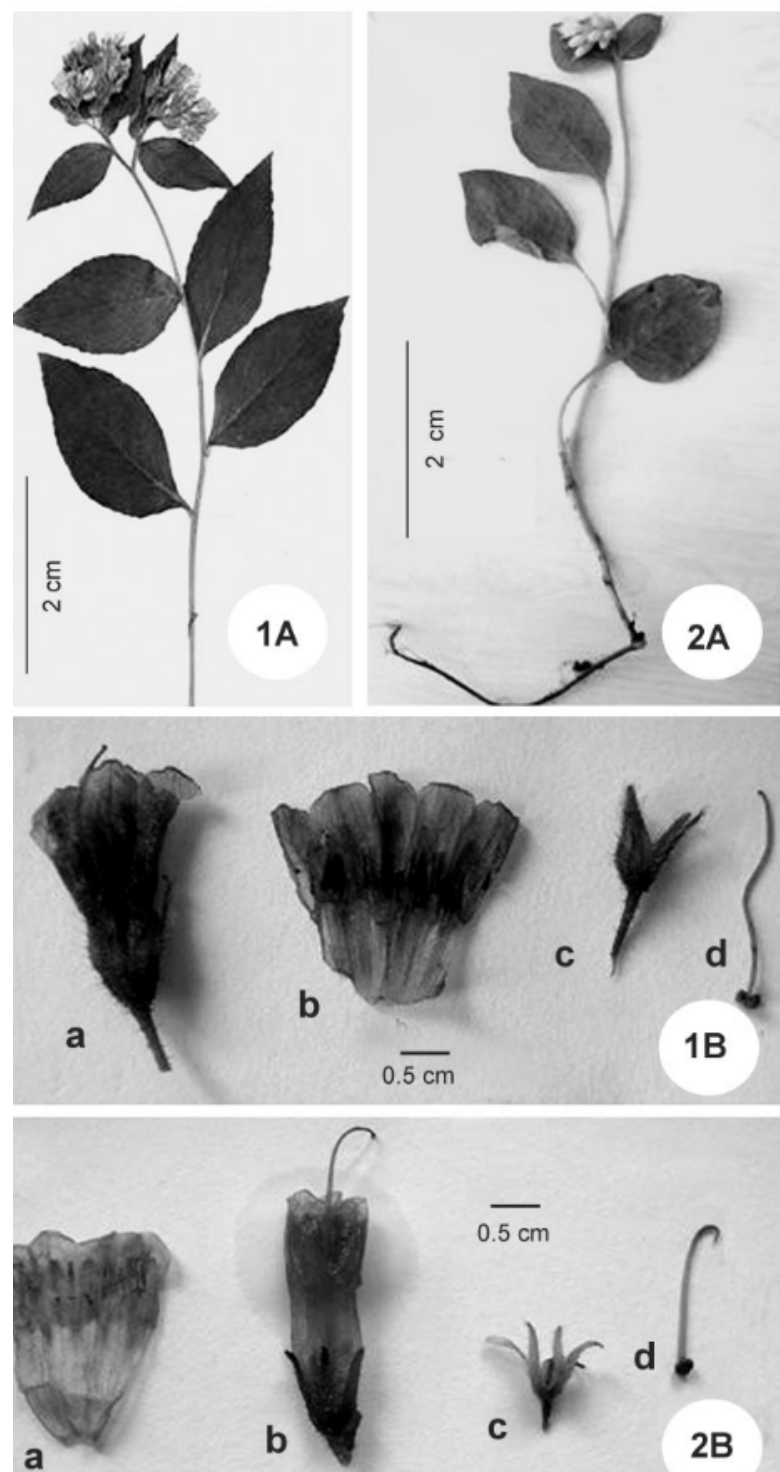

a

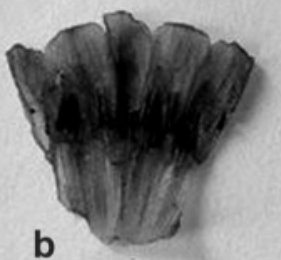

b

$\overline{0.5 \mathrm{~cm}}$
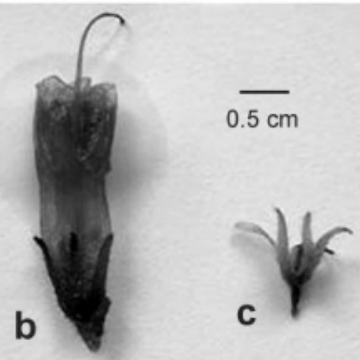
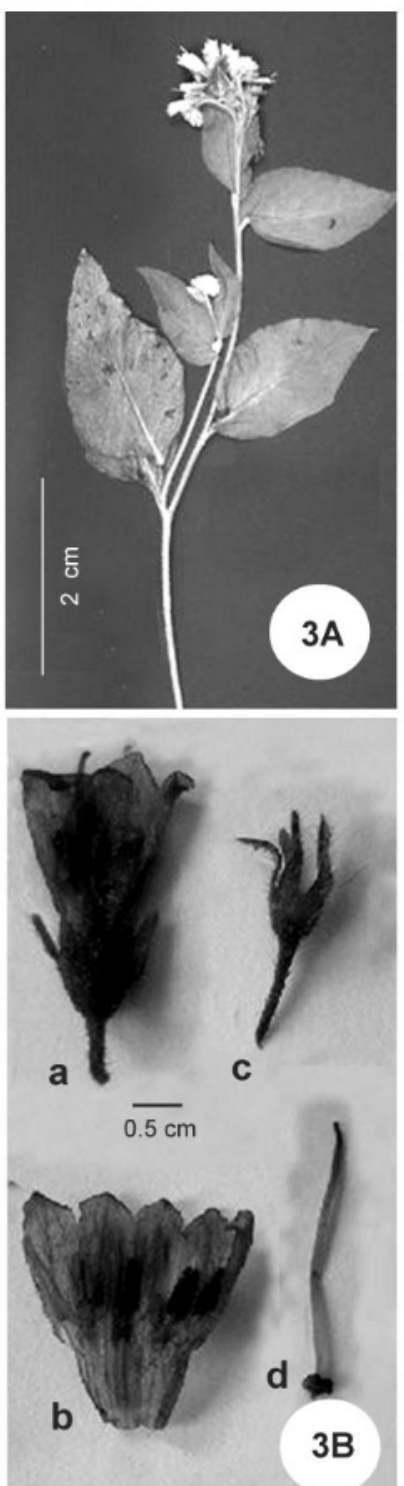

Figs. 1-3: 1. S. asperum (1A) General appearance. (1B) a- flower, b- corolla, c- calyx, d- stillus. 2. S. ibericum (2A) General appearance (2B) a- corolla, b- flower, c- calyx, d- stillus. 3. S. sylvaticum (3A) General appearance (3B) a- flower, b- flower, c- calyx, d- stillus. Bar $=2 \mathrm{~cm}(\mathrm{~A}) ; 0.5 \mathrm{~cm}(\mathrm{~B})$.

A transverse section of the lamina, midrib and both epirdermises was studied (Fig. 6-10). There is a single layered epidermis on the upper and lower surface of the leaf. Mesophyll consists of single layer of palisade parenchyma cells and 3-4 layers of spongy parenchyma cells. Palisade parenchyma cells are $11.75 \pm 0.53 \times 47.5 \pm 3.14 \mu$. Vascular bundle is collateral. Vascular bundles are surrounded by a parenchymatic bundle sheath. Leaf is bifacial. The upper and lower 
epidermis cells are covered with cuticle 1-2 $\mu$ thick. These cells are usually polygonal or irregular in form. Slightly undulate walls in upper and lower epidermis are observed in this species (Fig. 710). Stomata are anisocytic and anomocytic. Stomata occurs only in lower epidermis. Stomatal index is 21.86 for lower epidermis (Table 2). There are glandular and eglandular trichomes on the both epidermises. Eglandular trichomes are simple, generally unicellular and thin (Fig. 25 a-d). Uncinata shape trichomes present on the both epidermises (Fig. 25 a). Glandular trichomes are capitate and more dense on the lower epidermis than upper epidermis (Fig. 25 e-f).
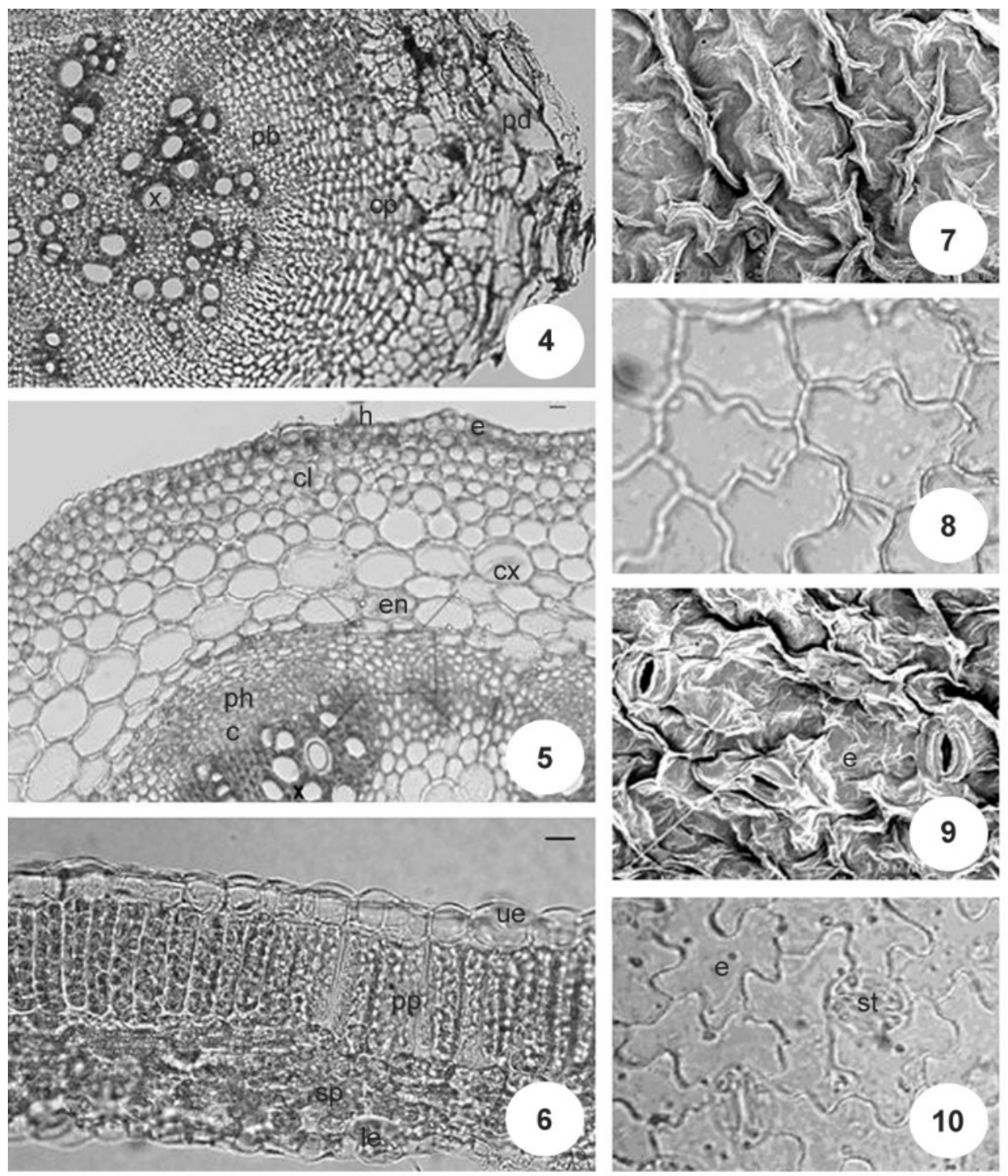

Figs. 4-10. S. asperum. 4. Cross-section of root. 5. Cross-section of stem. 6. Cross-section of leaf. 7-8. Upper surface of leaf (SEM) and (LM). 9-10. Lower surface of leaf (SEM) and (LM).

pd - peridermis, $\mathrm{cp}$ - cortex parenchyma, c - cambium, x - xylem, e - epidermis, cl - collenchyma, cx cortex, en - endodermis, ph - phloem, ue - upper epidermis, pp - palisade parenchyma, sp - spongy parenchyma, le - lower epidermis, st - stomata, h - hair. Bar $=30 \mu$ (Figs. 4-6). 
Symphytum ibericum: A transverse section taken from the root was observed as follows (Fig.11). Periderm is multilayered. Secondary cortex is multilayered. Cortex cells are $31.75 \pm 4.75$ $\times 23.75 \pm 2.48 \mu$. Cambium cells are distinguishable and 1-3 layers. Xylem is composed sclerenchymatic cells and tracheary elements. The pith consists of primary xylem elements (Table $3)$.
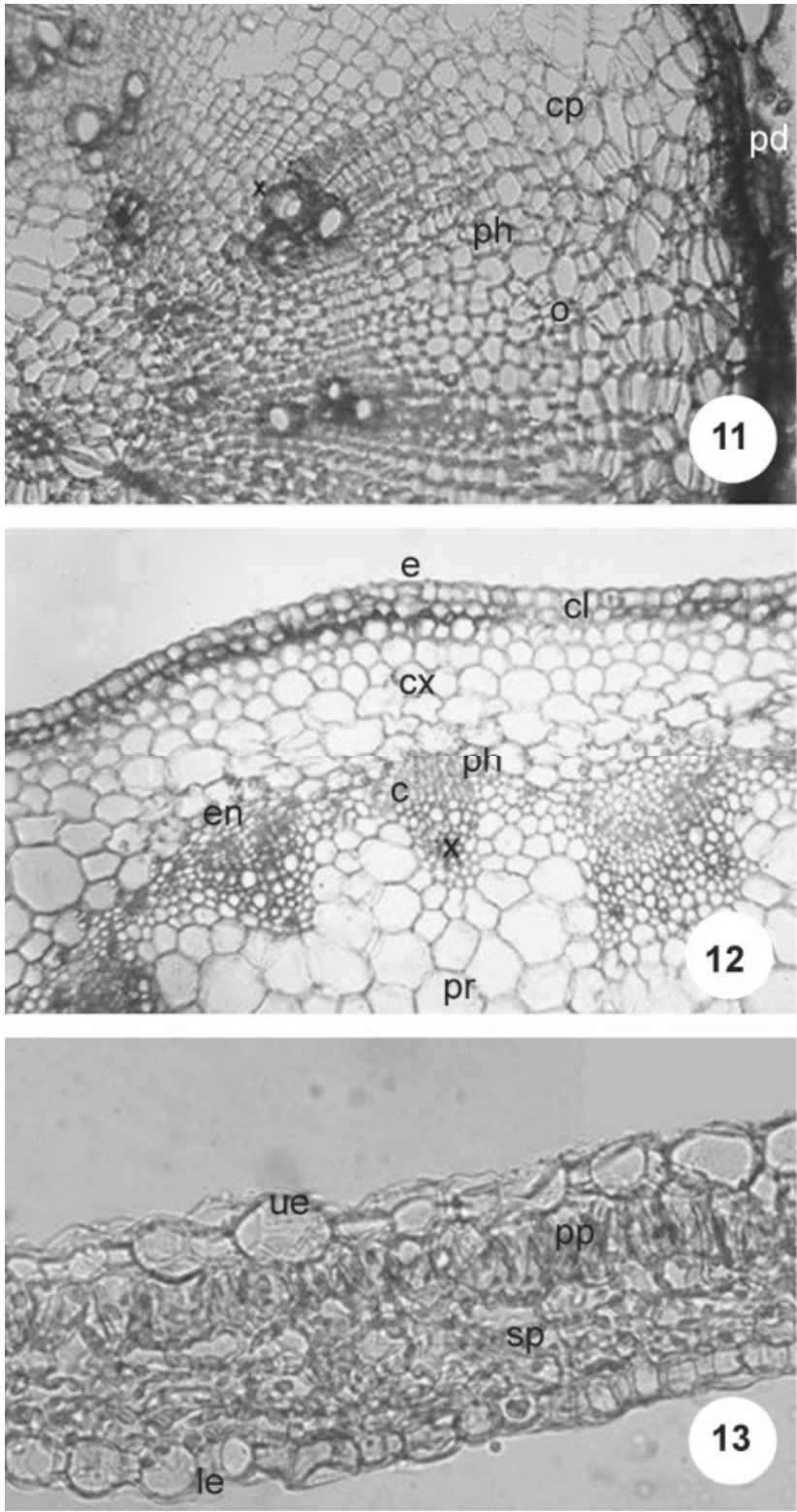
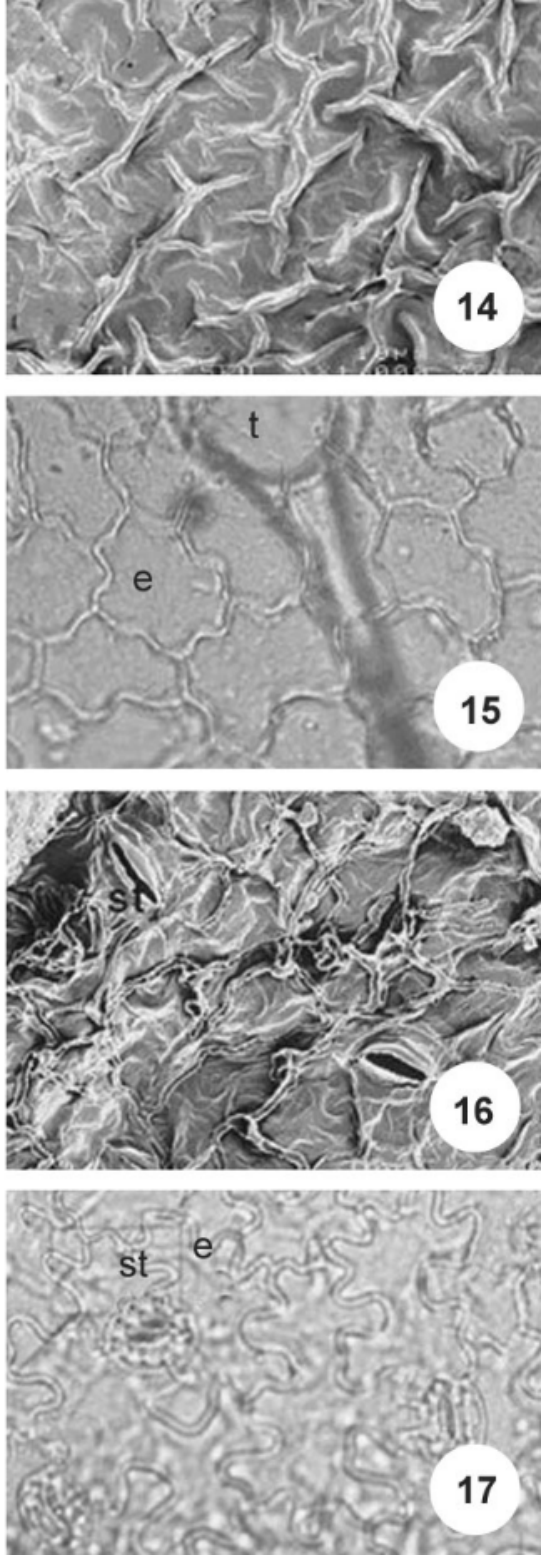

Figs. 11-17. S. ibericum. 11. Cross-section of root. 12. Cross-section of stem. 13. Cross-section of leaf. 14-15. Upper surface of leaf in SEM) and LM, respectively. 16-17. Lower surface of leaf in SEM and LM, respectively.

pd - peridermis, cp - cortex parenchyma, c - cambium, x - xylem, e - epidermis, cl - collenchyma, prr - primary pith rays, cx - cortex, en - endodermis, ph - phloem, pr - pith region, ue - upper epidermis, 
A transverse section taken from the middle part of the stem was studied (Fig.12). Cuticle layer is thin and trichomes are sparse. Epidermal cells consist of a single layer and orbicular or rectangular. These cells are $22.5 \pm 4.53 \times 16.5 \pm 1.24 \mu$. Two-three layers of collenchyma located under the epidermis. Cortex cells are $57.25 \pm 7.66 \times 35.75 \pm 5.90 \mu$ and multilayered. Endodermis is between cortex and vascular tissue. Endoderm cells with starch are one layer and distinguishable. Vascular bundles are of different sizes. Xylem and phloem elements are clear. Cambium is distinguishable. Phloem cells are $12 \pm 1.33 \times 8.25 \pm 0.99 \mu$. The pith consists of large parenchymatic cells (Table 3).

A transverse section of the lamina, midrib and both the epidermises revealed the following elements (Figs. 13-17). There is a single layered epidermis on the upper and lower surface of the leaf. Mesophyll consists of single layer of palisade parenchyma cells and three layers of spongy parenchyma cells. Spongy parenchyma cells are $19.25 \pm 3.43 \times 10.75 \pm 0.65 \mu$. Vascular bundle is collateral. Leaf is bifacial. The upper and lower epidermis cells are covered with thin cuticle. Epidermal cells are irregular in form. Upper epidermal cells are longer than lower epidermal cells. Anticlinal cell walls are slightly undulate in upper epidermis and strongly sinuous in lower epidermis (Figs. 14-17). Stomata are anisocytic and anomocytic. Stomata occur only lower epidermis.

The number of stomata is $43.2 \pm 2.44$ and the number of epidermal cells is $132 \pm 4.17$ on the lower surface.The stomata index is 26.5 for lower epidermis (Table 2). There are glandular and eglandular trichomes on the both epidermises. Eglandular trichomes are simple, short, long, generally unicellular, thin or thick. (Fig. $25 \mathrm{~g}-\mathrm{k}$ ) Uncinata shape trichomes present on the both epidermises (Fig. 25 g). Glandulars trichomes are capitate in form and more dense on the lower epidermis than the upper one (Fig. $251-\mathrm{m}$ ).

Symphytum sylvaticum: A transverse section taken from the root was observed as follows (Fig. 18). Periderm is multilayered. Secondary cortex is multilayered and occupies $30 \%$ of the root. Cortex consists of parenchymatic cells and secondary phloem. Parenchymatic cells are 26.25 $\pm 3.10 \times 4.73 \pm 2.34 \mu$. Cambium cells are distinguishable and 1-3 layers. Xylem is composed of sclerenchymatic cells and tracheary elements. The pith consists of primary xylem elements (Table $3)$.

A transverse section taken from the middle of the stem was observed (Fig. 19). Epidermal cells consist of a single layer and orbicular or rectangular. Trichomes are present on the cuticle. Collenchyma is three-four layered. Cortex cells are $78.25 \pm 5.43 \times 51.25 \pm 5.88 \mu$ and multilayered. Endodermis is between cortex and vascular tissue. The vascular tissues are collateral type. Bundles are of different sizes. Xylem and phloem elements are clear. Cambium is distinguishable. Diameter of vessel members are $35.5 \pm 6.4 \mu$. The pith consists of large parenchymatic cells (Table 3).

A transverse section taken from the lamina and both epidermises were studied (Figs. 20-24). Mesophyll consists of single layers of palisade parenchyma cells and three layers of spongy parenchyma cells. Palisade parenchyma cells are $11 \pm 0.55 \times 59.25 \pm 2.63$ and elongated. Spongy parenchyma cells are $19.25 \pm 3.43 \times 10.75 \pm 0.65 \mu$. Vascular bundle is collateral. Both the epidermises are covered with 1-2 $\mu$ thick cuticle. Upper and lower epidermal cells are irregular or polygonal in form. Upper epidermal cells are larger than the lower epidermis. Slightly undulate walls in upper epidermis and strongly sinuous walls in lower epidermis occur in S. sylvaticum (Figs. 21-24). Leaf is bifacial and hypostomatic. Stomata are anisocytic and anomocytic. The number of stomata is $17.25 \pm 1.02$ and the number of epidermal cells is $162.4 \pm 4.31$ on the lower surface. The stomata index is 27.5 in lower epidermal (Table 2). There are glandular and eglandular trichomes on both the epidermises. Eglandular trichomes are simple, short, long, 
unicellular or multicellular, thin or thick. (Fig. 25 n-o). Glandular trichomes are capitate form and more dense on the lower epidermal than upper one (Fig. 25 p-r).

In this study, the micromorphological and anatomical properties of $S$. asperum, S. ibericum and $S$. sylvaticum were examined. This is the first anatomical report on the three examined taxa of Symphytum.
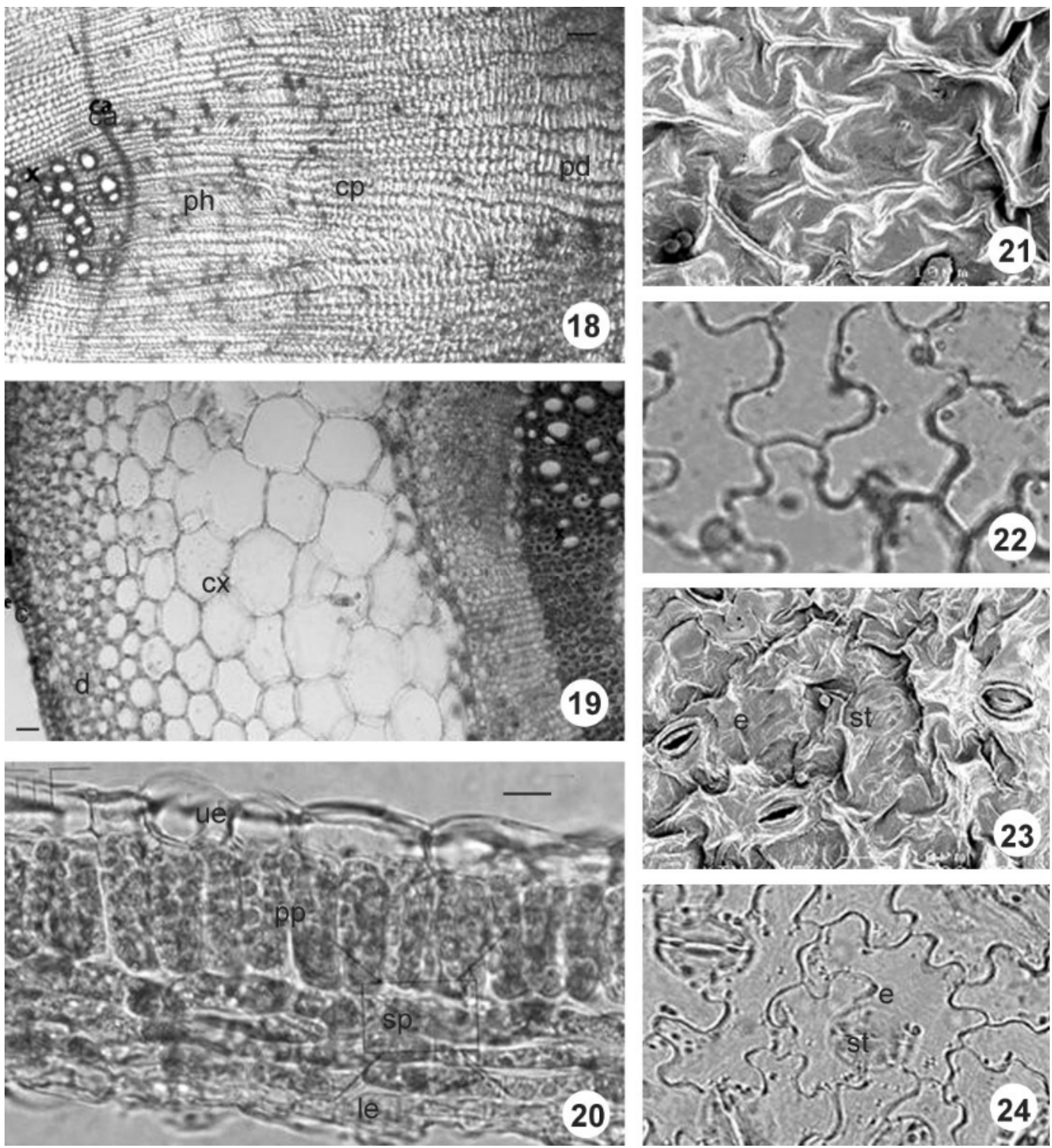

Figs. 18-24. S. sylvaticum. 18. Cross-section of root. 19. Cross-section of stem. 20. Cross-section of leaf. 2122. Upper surface of leaf in SEM and LM, respectively. 23-24. Lower surface of leaf in SEM and LM, respectively.

pd - peridermis, cp - cortex parenchyma, c - cambium, x - xylem, e - epidermis, cl - collenchyma, cx cortex, en - endodermis, ph - phloem, ue - upper epidermis, pp - palisade parenchyma, sp - spongy parenchyma, le - lower epidermis, st - stomata. Bar $=80 \mu$ (Fig.18); $35 \mu$ (Fig.19); 20 $\mu$ (Fig. 20). 

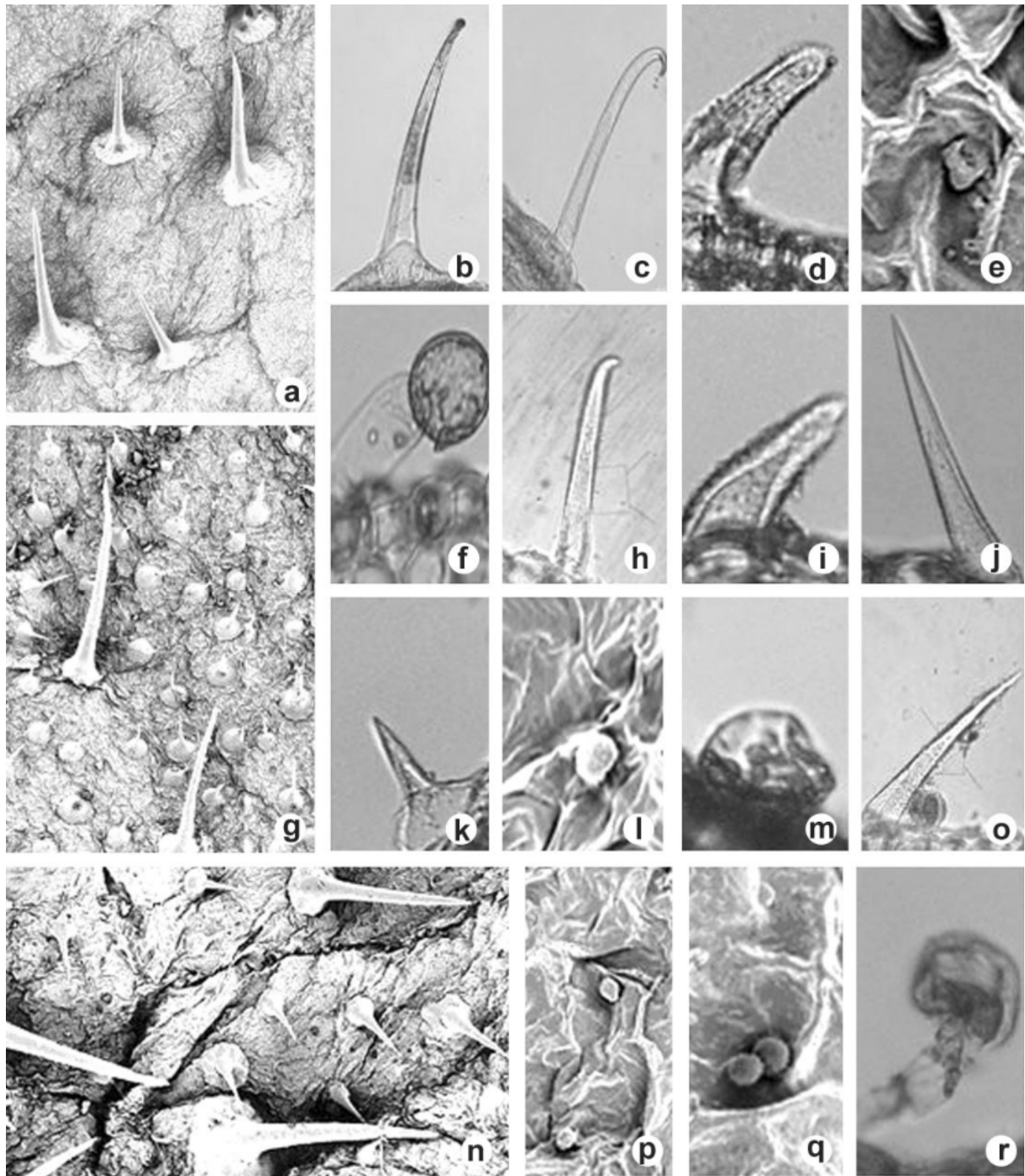

Figs. 25. a-d. Scanning electron micrographs (SEM) and light micrograps (LM) of eglandular trichomes of $S$. asperum; (e-f) Glandular trichomes of $S$. asperum (SEM and LM); (g-k) Eglandular trichomes of $S$. ibericum in SEM and LM, respectively; l-m) Glandular trichomes of S. ibericum in SEM and LM, respectively; (n-o) Eglandular trichomes of S. sylvaticum in SEM and LM, respectively. (p-r) Glandular trichomes of $S$. sylvaticum in SEM and LM, respectively.

Morphological characters such as length of the stem, shape of the leaf, type of the inflorescence and colour of the corolla are used as taxonomical characters. Although our results are generally similar with Wickens (1978), a few differences were found. Sizes of the basal and cauline leaves were reported for the first time in this study. In our study, it was found that the 
basal leaves were 8.5-11.5 $\times 4.5-9 \mathrm{~cm}$, the cauline leaves were 7.2-11.2 $\times 3-3.7 \mathrm{~cm}$ in $S$. asperum, the basal leaves were $8-11.2 \times 5-5.7 \mathrm{~cm}$, the cauline leaves were $3.2-7 \times 2-3.2 \mathrm{~cm}$ in $S$. ibericum, the basal leaves were 9.7-14.5 $\times 4-8 \mathrm{~cm}$ and the cauline leaves were $6.2-8.5 \times 3.2-3.4 \mathrm{~cm}$ in $S$. sylvaticum.

Metcalfe and Chalk (1979) and Watson and Dallwitz (1991) explained the characteristic properties of the family Boraginaceae. All examined taxa had secondary root structure and xylem was composed of sclerenchymatic cells and tracheary elements. In S. sylvaticum, root cortex occupied a large place compared to the other species. While the row number of collenchymatic cells vary among species, these cells are present in the stem of studied taxa. Endodermis are seen between cortex and vascular tissue in all these species. It was seen that phloem and cambium were more distinguishable and occupied larger place in S. symphytum.

Metcalfe and Chalk (1979) reported that there are centric or isobilateral mesophyll types in Boraginaceae. In this study it was seen that all examined species have bifacial leaf types. The same feature has been observerd in the leaves of Trachystemon orientalis (L.) G.Don. (Boraginaceae) (Akçin et al. 2004). Mesophyll consisted of single layer of palisade parenchyma cells and three layers of spongy parenchyma in S. ibericum and S. sylvaticum. Spongy parenchyma cells were three-four layered in $S$. asperum. Palisade parenchyma cells were long and thin in $S$. asperum and S. sylvaticum but in S. ibericum, their cells were short and thick. Metcalfe and Chalk (1979) reported that there are both anomocytic and anisocytic stomata in Boraginaceae but Özörgücü (1991) reported only anomocytic stomata in this family. Our findings conform with Metcalfe and Chalk (1979). The stomata are present only in lower part of leaves. Stomatal index is 27.5 for S. sylvaticum, 24.65 for S. ibericum and 21.86 for S. asperum.

According to Watson and Dallwitz (1991), glandular or eglandular and glandular trichomes are usually present in this family. In this study, it was found that all three species had simple, uniseriate trichomes. Trichomes are more dense in S.ibericum and S. sylvaticum. Glandular trichomes are capitate and more dense on the lower epidermis than upper epidermis in all the three species. These trichomes are unicellular and multicellular. Eglandular trichomes are simple, short, long, unicellular or multicellular, thin or thick.

The scanning electron microscope (SEM) is an ideal instrument for examining the surfaces (Cutler 1979). In this study, adaxial and abaxial surfaces of the species were investigated by SEM. It was seen that the epidermal cells are usually polygonal or irregular in form. The pattern of anticlinical cells may vary in different species and between the upper and lower epidermis of the same species. The same features have been observed in Schisandra (Yang and Lin 2005).

From the micromorphological and anatomical features of S. asperum, S. ibericum and $S$. sylvaticum it appears that some of the micromorphological and anatomical characters are useful to separate these species.

\section{References}

Akçin, Ö.E., N. Kandemir and Y. Akçin. 2004. A morphological and anatomical study on a medicinal and edible Plant Trachystemon orientalis (L.) G. Don (Boraginaceae) in the Black Sea Region. Turk. J. Bot. 28: 435-442.

Baytop, T. 1984. Türkiyede Bitkiler ile Tedavi (Treatments with plants in Turkey). Istanbul Univ. No. 40.

Chushenko, V.N., T.S. Prokopenko, N.F. Komissarenko, N. Zykova and O.E. Karamova. 1990. Carbohydrates of the roots of Symphytum officinale. Chemistry of Natural Compounds 26(4): 460-461.

Cutler, D.F. 1979. The Scanning Electron Microscope in recent systematic Plant Anatomy. In: Metcalfe C.R. and L. Chalk. ed. Anatomy of Dicotyledons I. Oxford University Press. 9-11, London.

Dudkin, M.S. and N.A. Denisyuk. 1984. Carbohydrates of Symphytum asperum. Chemistry of Natural Compounds 20(1): 13-18. 
Gürbüz, A. 1980. Şifalı Nebatlar (The Medicinal Plants), stanbul, 98.

Hills, L.D. 1976. Comfrey. Faber and Faber, London.

Jaarsma, T. A., E. Lohmanns, T.W.J. Gadella and T.M. Malingre. 1989. Chemotaxonomy of the Symphytum officinale Agg. (Boraginaceae). Plant Systematics and Evolation 167(3): 113-127.

Meidner, H. and T.A. Mansfield. 1968. Physiology of Stomata. McGraw-Hill, London.

Metcalfe C.R. and L. Chalk. 1979. Anatomy of Dicotyledons I. Oxford University Press, London.

Ozorgucu, B., Y. Gemici and I. Turkan. 1991. Karşılaştırmalı Bitki Anatomisi (Comparative Plant Anatomy), Izmir: Ege Univ. No. 129.

Rode, D. 2002. Comfrey toxicity revisited. Trends Pharmacol Sci. 23(11): 497-499.

Watson L. and M.J. Dallwitzs. 1991. The families of angiosperm: automated descriptions, with interactive identification and information retrieval. Australian Syst. Bot. 4: 681-695.

Wickens, G. 1978. Symphytum. In: Davis PH, ed. Flora of Turkey and the East Aegean Islands. Edinburgh University Press, Edinburgh 6: 380-386.

Yang, Z.R. and Q. Lin. 2005. Comparative morphology of the leaf epidermis in Schisandra (Schisandraceae). Bot. J. Linnean Soc. 148:39-56.

Yildırımlı, Ş. 2000. The chorology of the Turkish species of Boraginaceae family. The Herb J. Syst. Bot. 7(2): $257-272$.

(Manuscript received on 26 June, 2007; revised on 20 October, 2007) 